No 58 等・東側上杽管下部徚瓦一部破損。

No 59 害 東, 西側共上昇管下部クリンカー附着

No 68 管・No 69 等・No 68 押出の際西側装 入口下部を押切つた雽 No 69 に影響 し東侧押出され膨脤している。

No 70 窭 No 71 烾 No 3 裝入口下西侧中央 部 No 68 と同樣 No 71 側一押出し ている。

上迹の如く (13 嘿に附き) 稍々大きい破損部のある ことか明らかになつている，之等の大部は No 2, 3 装入口下即ち爐の中央部て爐壁は爐端との收縮の差に より切裂赾生じ易く，且つせい弱になつている事を示 している，郎ち爐頁高さの收縮は中央部力兩端より極 めて大なる事を示したが之等の影響及て幅の收縮に就 て子端部と中央部の冷却罝度差による收縮纱況か異な る，之等の影響によるものと推考される。又破損狀沉 よりして靾出の際に於て押出穖の無理押をなした孚に 生したるものもあると考えられる。

コークスガス犲口周りの破損贆況に關しては調查困 難なため明らかては無いか堷熟室に關しては No 28 筧を表裏共瑓瓦を取り除いて調查した結果は相當良好 壯熊にあるとの报告に接している。

偷完全な調查を充分に行い檢討するのてなくては本 コークス㠠の再操業可能なりや否やに就ての正確な見 透しは斷言し得ないのは勿論てあるか，八幡釜石のコ ークス爐再開及び其の後の爿況を鹳案寸れは，コーク

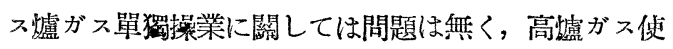
用に關しても其の手入如何に依ては決して不可能ては 無いと思料せられる。

\section{$[V]$ 結䨐}

筆者は閧畑製鐵所のコークス爐に就き其の休止前に 於ける分散蒸込法に泝る輕操業の經過を述へると共に 其の能力の $70 \%$ 以下の操業を操業溫度，敒用熟量よ り一應輕㙅業とし日つ最低操業は㠠體に及瀆す影響を 無視する場合は其の能力の 20\% 程度てあることる計 算上より明かにした。分散蒸込法は爐盗啁節及び空㲵 導入防止に相當の熟懒と手數を要するか長期の輕操業 を行了場合には爐況を均一化し日つ操業の伸縮性に富 み有效な一方失てもることを認めた。第2に徐冷休止 作䍴に關して記远したが概ね順啁な溫度降下と之に桝 5收縮狀况を示した，且つ冷却後の爐哣內部は中央部 ふ潲々せい弱になつている事を認めたが，概して爐の 爿態は所期の瑔想よりも良好てあることを述へた。

最近コークス爐の休止並ひに其操業に關する一般的 な定恱として特に重要なる事項としては, 徐冷の際盧 締ホルトは締ない事及び冷却後熅體內部等の目地押は 極力避け再操業の溫度上昇後行了事，冷却後は直ちに 內容物は取出し空等に寸ること等か强调されているこ とを附言する。

現在コークス爐新設には約 1 萬 $\mathrm{t}$ の耐火熯瓦，2 年 近くの年月と數億圓の金額を要するのてある，從つて 休止爐の再開は寔に重要なる事項てあり，今後共原料 炭の相當部分を國外に依存せさるを得好我國に於て萬 一にも止む得ず輕㙅業或は休止作業をせさるを得婸 合をる考慮し其の參考に資すると共に，終戰前後の各 所コークス爐の苦難に充ちた操業の一つの記錄として 敢て本稿を寄せた次第でる。

終りに臨み終始御慜切なる御指導と御缏達を賜つた 錂部部長に對し厚く感謝の意を䘚する。

\title{
八幡製鐵所に於ける銑鋼一貫熱流れ
}

——昭和 23 年9月11日第237回例會請演—

日鐵 八幡製驖所設樂正雄

\section{[I]緒要}

八幡製鐵所監理部熱管理掛に於ては各種然料並に禣 助熹量 (電力, 蒸鿑, 水) の需給統制忞行い, 又各工 埸の熱泪定にも從事している。此等の結果を牛期每に 漗括して, 所內昱體の熟流れ圖を作成し，關係方面に
配布している。其の資料を基焚にして，銑铜一貫作業 を行つている當所の, 昭和 22 年下期に於ける䓡流れ に就き解詨を試みる。

\section{[II 燃料の需給㩆況}

昭和 22 年下期に於て當所にて取报つた燃料の品位 
(發㪟量)を示せは第 1 表の如くてある。燃料の墢熱量 は一般に斷熱式熱量計て測定しているのて，總(高位) 發熱量を以てあらわされる。從つて熱量は全部高位て 示す事にした。

\section{第 1 表 燃料 の品位}

(Ho $\mathrm{kcal} / \mathrm{kg}$ or $\mathrm{kcal} / \mathrm{m}^{3}$ )

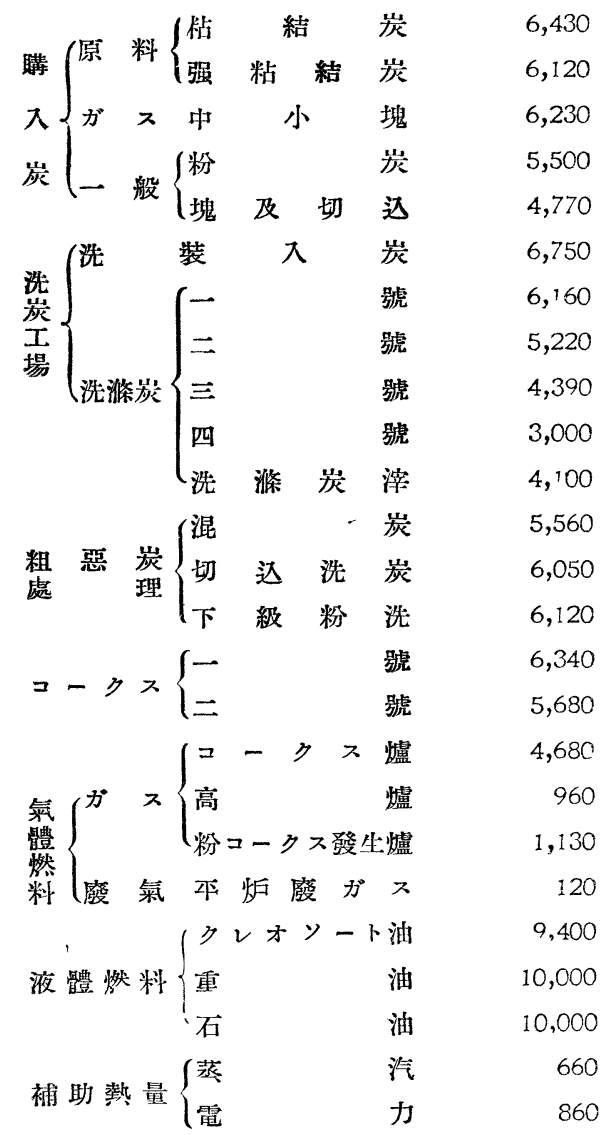

一般用蒸汽はゲーシ壓力 $5 \mathrm{~kg} / \mathrm{cm}^{2}$, 溫度 $160^{\circ} \mathrm{C}$ のて, ェンタルピーを $660 \mathrm{kcal} / \mathrm{kg}$ と，電力は理論 値の $860 \mathrm{kcal} / \mathrm{K}$ W.H を探用した。

廢熱ホイラーに行?平㠠廢カスの顯熱は, 此熱 03 $\mathrm{kcal} / \mathrm{m}^{3} \mathrm{C}$ 塭度 $400^{\circ} \mathrm{C}$ として, $120 \mathrm{kcal} / \mathrm{m}^{3}$ になる。

(A) 固體燃料

\section{(a) 石 炭}

約 687 千 $\mathrm{t}$ の石炭を購入し，コークス用原料炭てあ る强粘結炭か 186 千 $\mathrm{t}$, 弱粘結炭か 290 千 $\mathrm{t}$ 入荷し, ガ ス發生爐用炭としての中小塊炭が75千 $\mathrm{t}$ てあり， 一般用炭ては粉炭か 104 千 $\mathrm{t}$, 塊及切込炭か31 千 $\mathrm{t}$ か洀入されている。

此等の石炭は主として，何處の㞸鑛から來ているか を调查したのが第 2 表てある。aは各炭種別の\%を示
し、 $\mathrm{b}$ は購入炭全體の割合を示す。占領軍の好意によ るカナダよりの輸入炭か光つている。

\section{第 2 表 入荷石炭の割合}

t a \%

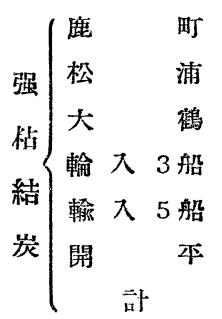

66,259

3567

b \%

70,634

3804

965

29,168

1570

1028

8,792

473

425

1,169

063

128

017

9,702

523

185,724

1.41 -

結 $\left\{\begin{array}{lll}\text { 筑 } & & \text { 豐 } \\ \text { 炭 } & \text { 九 } & \text { 州 } \\ \text { 三 } & & \text { 瀨 } \\ \text { 高 } & & \text { 鳥 } \\ \text { 輸 } & \text { 入 } & 4 \text { 船 } \\ \text { 三 } & & \text { 他 } \\ \text { 土. } & & \text { 戚 }\end{array}\right.$

80,003

100

27.04

2759

1165

38,289

1320

5.58

149,248

51.46

21.74

2,730

094

040

9,057

312,132

2,477

085

036 ,

8,195

284

119

289,999

100

4224

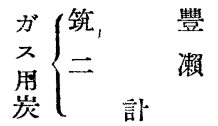

51,083

6789

744

24,144

32.11

3.51

75,227

10.95

粉 $\left\{\begin{array}{lll}\text { 炭 } & & \text { 豐 } \\ \text { 西 } & \text { 九 } & \text { 州 } \\ \text { 三 } & & \text { 瀨 } \\ & & \text { 池 } \\ & \text { 計 } & \end{array}\right.$

79,703

100

11.60

9,929

952

145

14,664

1405

214

45
104,341

004

100

1519

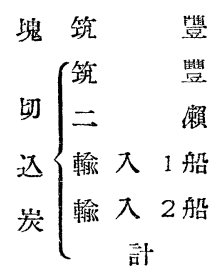

60

4,592

9,355

9,050

8,404

31,401

總 計 $686,752 \quad 0 \quad 100$

100

$1464 \quad 067$

$2976 \quad 136$

$2880 \quad 132$

$2680 \quad 123$

$100 \quad 458$

八幡製鐵所に於る石炭の需給狀況を第 3 表に表示し た。强粘結炭は全部洗炭されてコークス爐に行き，弱 粘結炭はコークス嚧の他に一部はホホイラーに使用され ている。(粉炭の粗惡化並に絕對量の不足から止むを得 ない處置てある）ガス用炭は平爐並に工作（鑄鋼）に 附屬する發生爐や，石炭焚(手焚)の鋼材加㓐爐，及び 煤瓦の燒成箽に使用されている。粉炭の內比較的良質 なるのはそのま入汽矔場に運び，下級な粉炭は洗炭或 は绲炭して品質を向上させてからチェーングレートス トーカーて燃燒させている, 塊及切达炭子大部分は洗 炭し一部はそのま〉機關車用炭として使用している。 
第 3 表石孷の需給狀況 $(t)$

\begin{tabular}{|c|c|c|c|c|c|c|c|c|c|c|}
\hline & & & 原 & 炭 & ガス用炭 & - & 炭 & 合 & 計 & \\
\hline & & & 强 佔 結 & 弱 佔 結 & 中 小塊 & 炭 & 塊及切达 & 合 & 1 日富 り & \\
\hline 入 & (贈 & 入 & 185,724 & 289,999 & 75,227 & 104,341 & 31,461 & 686,752 & 3,753 & 952 \\
\hline & 貯 藏 d & $\eta$ & - & - & 18,714 & - & 15,833 & 34,547 & 189 & 48 \\
\hline & 合 & 計 & 185,724 & 289,999 & 93,941 & 104,341 & 47,294 & 721,299 & 3,942 & 1000 \\
\hline & 洗 & 岸 & 150,221 & 220,640 & - & 15,541 & 25,385 & 411,787 & 2,250 & 572 \\
\hline & 混 & 炭 & - & 21,080 & - & 19,232 & 780 & 41,092 & 225 & 57 \\
\hline & 本 & 爐 & - & 90 & 74,737 & - & 160 & 74,987 & 410 & 104 \\
\hline 出 & 筐 & 延 & - & 57 & 9,594 & 30 & 273 & 9,954 & 54 & 14 \\
\hline & 爐 & 材 & - & 15 & 3,644 & - & 96 & 3,755 & 21 & 05 \\
\hline & 汽 & 鑵 & - & 43,462 & 120 & 62,832 & 666 & 107,080 & 585 & 148 \\
\hline & 運 & 輸 & - & 470 & 63 & 3,512 & 18,831 & 22,876 & 125 & 3.2 \\
\hline 量 & $I$ & 作 & - & 265 & 4,709 & 1,318 & 618 & 6,910 & 38 & 09 \\
\hline & 其 & 他 & - & 314 & 610 & 1,234 & 485 & 2,643 & 14 & 03 \\
\hline & 賩 & 藏 & 35,503 & 3,606 & 464 & 642 & - & 40,215 & 220 & 56 \\
\hline & 合 & 計 & 185,724 & 289,999 & 93,941 & 104,341 & 47,294 & 721,299 & 3,942 & 100 \\
\hline
\end{tabular}

結局 1 日の使用量は $3,722 \mathrm{t}$ て，その $57 \%$ は洗炭 工場に行き，15\%がホィラーて，10\% か平㖃に使用 きれている。

\section{(b) コークス}

石爫の入荷か思わしくないために，高爐用ュークス ( 1 號コークス)の他に, 装入炭の 4 割を節約して 2 號 洗滌炭て代用した 2 號コークスを製造し，專ら石灰下 ロマイトの燒成や粉コークス發生爐に使用し, 良質コ ークスの節約に勉めている。㸮コークスは篩分して中
粉 $(25 \sim 15 \mathrm{~mm})$ ，小粉 $(15 \sim 9 \mathrm{~mm}$ ), 微粉 (9 mm 以 下）と區別し，中粉は石灰及トロマイト，小粉は粉 一クス發生爐, 微粉は然結工場に使用している。 生產量は 1 號コークス186千 t, 2號 12 千 $\mathrm{t}$ 及び粉 コークス13千tて合計 211 千 $\mathrm{t}$ てむうて, 1 日の消 費量は 1,169t てあり，その $81 \%$ は熔鑛爐に，5\% か石灰トロマイト，4\% か燒結に使用されている。そ の詳細は第 4 表の通りてある。

\section{第 4 表コークスの需給狀況 $(\mathrm{t})$}

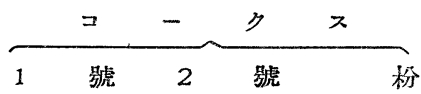

入 $\left\{\begin{array}{cccc}コ & - & \text { ク } & \text { 爐 } \\ \text { 量 } & \text { 貦藏 } & \text { ょ } & y \\ \text { 合 } & \multicolumn{2}{c}{\text { 計 }}\end{array}\right.$ 量 $\left\{\begin{array}{lr}\text { 高 } & \text { 爐 } \\ \text { 爐 } & \text { 材 } \\ \text { 工 } & \text { ， 作 } \\ \text { 燒 } & \text { 結 } \\ \text { 石 灰 トロマイト } \\ \text { 其 } \\ \text { 合 } & \text { 䚺 }\end{array}\right.$

(c) 加工炭

石炭事情の惡化に件い，量的な生產をのみ强いたせ

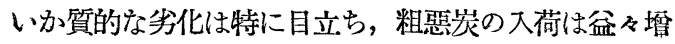

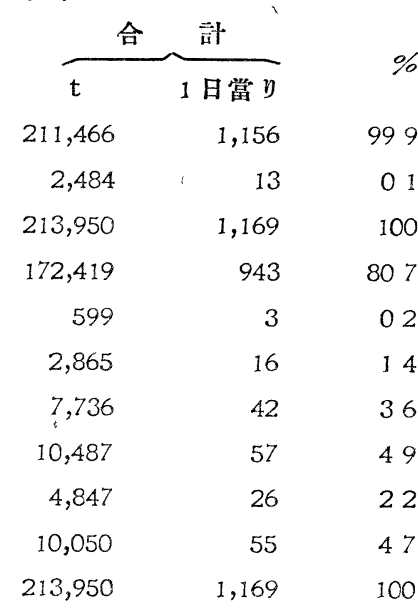

す一方てある。燃堯室の改造等に如何程留意してb，

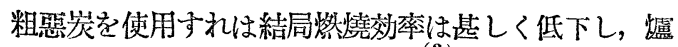
の熱效率も期待に区する結果となる。 
そこで當所に於ては粗惡炭は洗炭工場に䢪るか，混 㷋工場に迴して，洗炭或は良質炭と混合して品質を向 上させてから使用している。 $4,770 \mathrm{kcal} / \mathrm{kg}$ 程度の切 込炭を洗炭すると $6,050 \mathrm{kc}=1 / \mathrm{kg}$ にはなるので，穴の 中の 4 割は最質炭として混炭場に邆り，3割は直接术 イラーに使用している。下級粉炭子 $4,900 \mathrm{kcal}$ 程度 のものが $6,120 \mathrm{kcal}$ 、にはなるので，大部分は良質炭

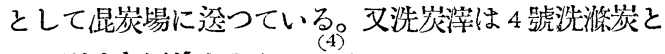
して別途な用途を與えている。

混炭場に於てはこれらのものに粗惡炭を加之，或は 若干の原料炭を混合して, 大體品質を一定 $(5,560 \mathrm{kcal})$ にして，汽鑵場て安心して使用される楾に努力してい

\section{第 5 表 加工炭（租惡㞸處理）の需給狀況}

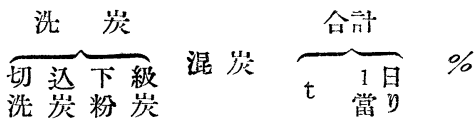

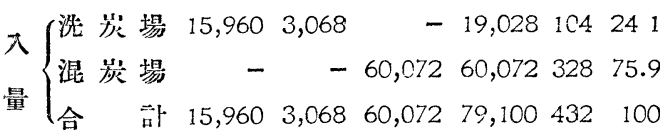

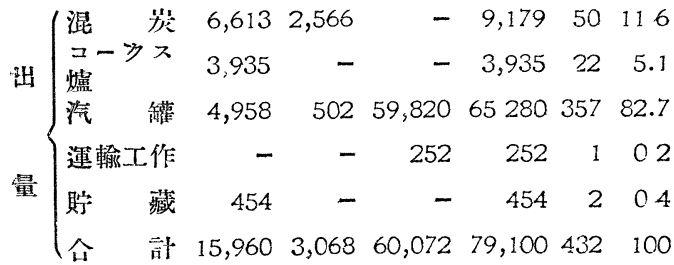

る。

此等の作業は多忙な本業をるつ洗炭工場て，副業的 に操作しているので，1日 $450 \mathrm{t}$ 程度の處理しか行わ れていないか，將來は大々的に擴張する計畫である。 詳しい需給狀況は第 5 表に示した。

(d) 洗临炭

原料炭を洗炭した場合に生する摔は 2 號及び 3 號洗 滌咴であるか，2 號は再洗して 1 號洗像炭を回收して いる。粗惡炭（切込炭及で下級粉炭）の洗炭涬は，こ れらのるのより更に品質か洛らるのて，別に 4 號洗临 炭と命名している。

第6表に示寸如く，1 號洗燃炭は上級炭として湿炭 に使用され，2號先條炭は主として混炭により或は直 接にホイラーに使用され，或は 2 號コークスの原料と してコークス㠠に裝入旮，又セメントのロータリー キルンに用いられている。3號珗㴪炭は大部分配炭公 團を通じて外販され，一部は寄宿舍や病院の燃料に使 用している。4號珗源炭は品質力渄常に落ちるので, 現在の所全部院藏している。(之に 1 割程度の廢油を渡 潤させ，「化成炭」として新用途を研究中である。泿澱 炭站は所謂ドべ炭として, 市中の浴場に支給し, 從業 員やその家族の便をはかつている。

結局洗桜炭の $50 \%$ 外販され，9\% は昆炭場，7\% ははコークス爐，6\% は蜢接ホイラーに揆られてい る。

第 6 表洗源炭の需給狀況 (t)

洗

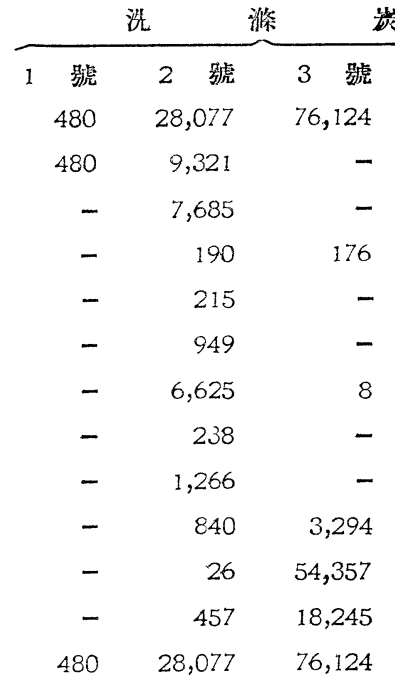

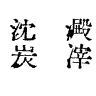

2, 189

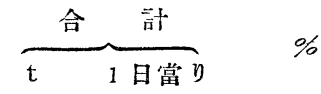

109,104

9,801

$596 \quad 100$

$54 \quad 9.1$

7,685

366

215

949

6,633

238

1,266

6,223

54,383

21,036

109,104

2,334
$\%$

00

0

03

2

08

60

C. 2

12

57

50.0

19.5

100

(B) 液體燃料

石炭の不足を補うために，聯合軍の好意により鐱入 された重油は，(大部分 B重油で 1 部ね C重油であつ

た） $100 \mathrm{t}$ 年㠠に殆んと使用し, 鋼材加熱爐に於てはガ スとの倱等を行つた。

重㣙は粘度が非常に高いのて，加熱設備のない所で 
は使用方困䧼てある。又硫黃分它高く，乞の絕體量も 不足しているのて，コークス㠠副意物てあるクレオy 一ト油を，平㠠，鋼材加熱爐，燒結に便用している。 內燃機用石油は主として，トラックや船船に使用芑 れた。

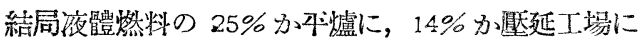

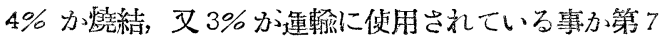
表に示されている。

(C) 氣體然料

高盧ガスは．岑素平衔より計算して，出銑 $\mathrm{t}$ 當り 4,551 $\mathrm{m}^{3}$ 發生しているか，38\%は㷫風盧に，13\%が ホイラー，11\%か壓延工場，5\%がークス煴，3\%が 本㠠，1\%か化成，2\%力其の他で，其の殘りか放散と いら事になる。

粉コークス發生爐がスは, 装入コークス $\mathrm{t}$ 當り 2,700 m" 發生するか，發熱量か， $1,100 \mathrm{kcal} / \mathrm{m}^{3}$ 程度こ高盧 ガスに類似しているので，高㠠カスと混合して使用し ている。

コークス㠠ガスの發生量は單位か一つ下つて，装入 炭當り $328 \mathrm{~m}^{3}$ でり，44\%はコークス獹に，23\%が
第 7 表 液體燃料の露給狀況 $(\mathrm{t}$ )

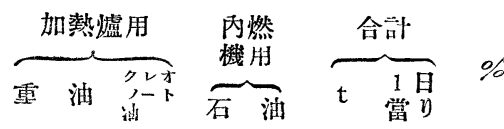

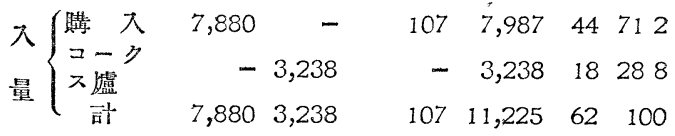

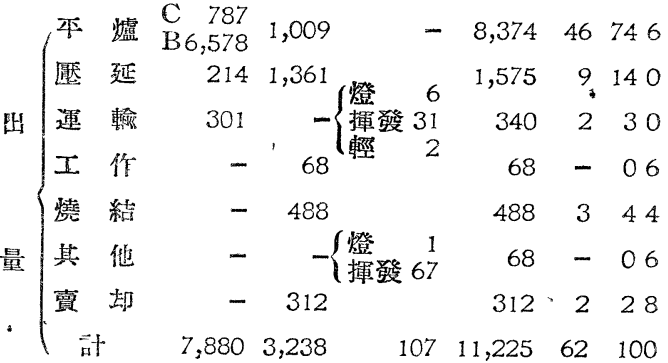
壓延工場に，14\%がホイラーに，9\%か本爐に使用さ れている。

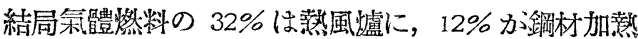
㠠，13\%かホイラー，12\%がコークス爐，等に使用さ れている事となる。(第8表參照)

\section{第 8 表象蹬然料の需給狀況 $\left(\times 10^{3} \mathrm{~m}^{3}\right)$}

\begin{tabular}{|c|c|c|c|c|c|}
\hline 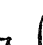 & 高 & & 纑 & 629,830 & - \\
\hline 大 & $=-$ & $y$ ス & 爐 & - & - \\
\hline & 枌コー & クス發会 & 生蠦 & - & 16,577 \\
\hline & & 許 & & 629,830 & 16,577 \\
\hline & - & $y \pi$ & 爐 & 30,131 & 13,829 \\
\hline & 高 & & 蹎 & 236,510 & - \\
\hline & 本 & & 爐 & 15,569 & - \\
\hline & 壓 & & 趧 & 66,394 & $1,1: 7$ \\
\hline & 化 & & 成 & 703 & 9 \\
\hline & 汽 & & 鑵 & 83.607 & 1,622 \\
\hline & I & & 作 & - & - \\
\hline & 其 & & 他 & $1 ", 101$ & - \\
\hline & 賣 & & 却 & - & - \\
\hline & 放 & & 散 & 85,815 & - \\
\hline & & 計 & & 629,830 & 16,577 \\
\hline
\end{tabular}

[目] 補助熱量の需給狀況

電力は 66\%を發電し，34\%を日發より買電し，其 の合計は $26,300 \mathrm{~kW}$ てある。其の使用弲態は $35 \%$ か 動力（主として揚水用ポンプ），21\%万崕趜工埸（主

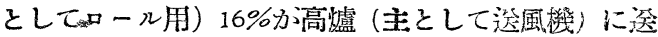
られている。

蒸汽は 1 時間 $214 \mathrm{t}$ 發生され, 50\%か發電用々, .2\%
ロークス爈合 計 1 日當り $\%$

$\begin{array}{rrrr}- & 629,830 & 3,442 & 851 \\ 94,511 & 94,511 & 516 & 12.7 \\ - & 16,577 & 91 & 2.2 \\ 94,511 & 740,918 & 4,049 & 100 \\ 41,424 & 85,384 & 467 & 11.5 \\ - & 236,510 & 1,293 & 320 \\ 8,182 & 23,751 & 130 & 32 \\ 21,366 & 88,877 & 486 & 120 \\ 3,943 & 4,655 & 25 & 06 \\ 13,402 & 98,631 & 539 & 13.3 \\ 1,685 & 1,685 & 9 & 02 \\ 2,895 & 13,996 & 76 & 19 \\ 1,614 & 1,614 & 9 & 02 \\ - & 185,815 & 1,015 & 25.1 \\ 94,511 & 740,918 & 4, \mathrm{C} 49 & 100\end{array}$

が高爐 (主として邆風機)，11\%が伦成(主として蒸溜 用)，10\%が平爐(主として發生爐)に使用されている。 水は凈水 $(6 \%)$, 海水 $(54 \%)$, 淡水 $(40 \%)$ 併せて 1 時間 18,500tを供給し，35\% 加高盧（主として濕式 清淨機)に，13\% か動力（主としてふイラー）、12\% が八幡， F烟，小倉市民用水道に，12\%か汗㠠（主と して冷却水）に使用されている。其等の狀況は第 9 表 
第 9 表 補助熱量の需給狀況

\begin{tabular}{|c|c|c|c|c|c|c|c|c|c|c|}
\hline & & 電 & f & & & 蒸 & 汽 & & 水 & \\
\hline i & & $\times 10^{3} \mathrm{KWH}$ & $\mathrm{KW}$ & $\%$ & $\mathrm{t}$ & $t / h$ & $\%$ & $10^{3} t$ & $t / h$ & $\%$ \\
\hline . & 入 & 39,089 & 8,900 & 33.9 & - & - & - & - & - & - \\
\hline 家 發 & 生 & 76,272 & 17,366 & 66.1 & 937,623 & 213.5 & 100 & 81,285 & 18,508 & 100 \\
\hline 計 & & 115,361 & 26,266 & 100 & 937,623 & 213.5 & 100 & 81,285 & 18,508 & 100 \\
\hline & 炭 & 2,010 & 458 & 1.7 & 6,020 & 1.3 & 0.6 & 574 & 131 & 0.7 \\
\hline$-y x$ & 爐 & 2,652 & 604 & 2.3 & 6,276 & 1.4 & 0.7 & 4,730 & 1,077 & $5^{8}$ \\
\hline 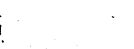 & 爐 & 18,005 & 4,100 & 15.6 & 109,897 & 25.0 & 11.7 & 28,714 & 6,537 & 35.3 \\
\hline & 爐 & 3,002 & 684 & 2.6 & . 95,235 & 21.7 & 10.2 & 9,805 & 2,233 & 12.1 \\
\hline 氣 & 爐 & 6,546 & 1,490 & 5.7 & - & . & - & - & - & - \\
\hline & 延 & 24,530 & 5,584 & 21.2 & 33,995 & 7.7 & 3.6 & 6,875 & 1,565 & 8.4 \\
\hline & 成 & 1,973 & 449 & 1.7 & 106,474 & 24.2 & 11.4 & 7,216 & 1,643 & 8.9 \\
\hline & 材 & 859 & 196 & 0.7 & - & - & - & - & - & - \\
\hline & 方 & 40,088 & 9,127 & 34.8 & 40,441 & 9.2 & 4.3 & 10,649 & 2,425 & 13.1 \\
\hline & 輸 & 1,221 & 278 & 1.1 & 239 & - & - & - & - & - \\
\hline & 作 & 2,941 & 670 & 2.5 & 26,773 & 6.5 & 3.1 & - & - & - \\
\hline & 結 & 2,956 & 673 & 2.6 & - & - & - & - & - & - \\
\hline$x>$ & r & 1,192 & 271 & 1.0 & - & - & - & - & - & - \\
\hline 分二發 生 & 爐 & 288 & 66 & 0.3 & 4,142 & 0.9 & 0.4 & - & - & - \\
\hline & 他 & 6,923 & 1,576 & 6.0 & 38,099 & 8.6 & 4.0 & 2,744 & 625 & 3.4 \\
\hline . & 却 & 175 & 40 & 0.2 & - & - & - & 9,978 & 2,272 & 12.3 \\
\hline & 電 & - & - & - & 470,032 & 107.0 & 50.0 & - & - & - \\
\hline 計 & & 115,361 & 26,266 & 100 & 937,623 & 213.5 & 100 & 81,285 & 18,508 & 100 \\
\hline
\end{tabular}

に示した。

\section{[IV]八蟠製戜所の熱平衡}

23 年度下期に於ける八幡製鐵所全體の 熱平衡を調 查したのが第 10 表である。購入石炭としての㷫量が

\section{第 10 表 八幡製鐵所の熱平德}

入

熱

$\mathrm{t} \quad \mathrm{t} / \mathrm{d} \times 10^{6} \mathrm{Kcal} \%$

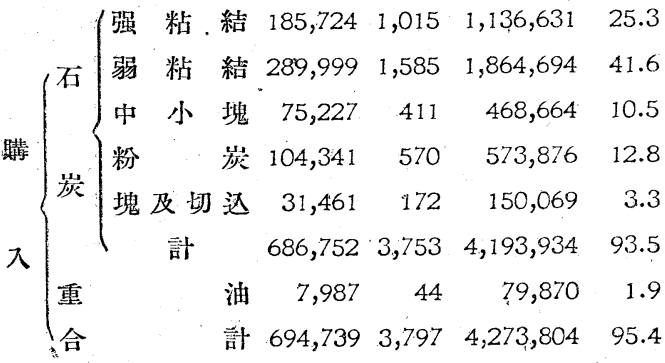

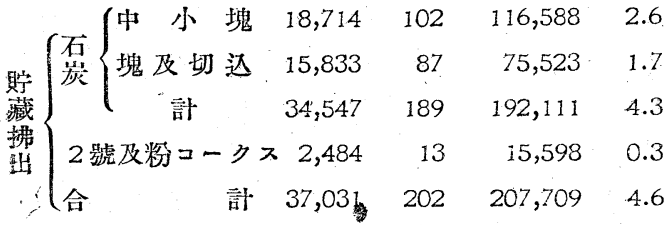

總
한 $731,770 \quad 3,999 \quad 4,481,513 \quad 100$

\section{出熱}

\begin{tabular}{|c|c|c|c|c|c|}
\hline & (2號及3號洗临炭 & 54,383 & 297 & 2,522 & - \\
\hline & ב ( 1 號及 2 號 & 927 & 5 & 5,605 & 0.1 \\
\hline & 粉 & 1,266 & 7 & 8,026 & 0.2 \\
\hline & 計 & 2,198 & 12 & 13,631 & 0.3 \\
\hline & クレオソート油 & 312 & 2 & 2,933 & 0.1 \\
\hline & コークス爐ガス & $1,614 \mathrm{~m}^{3}$ & 9 & 7,554 & 0.2 \\
\hline & 計 & - & - & 26,640 & 0.6 \\
\hline & 强 & 35,503 & 193 & 217,278 & 4.8 \\
\hline & 弱 & 3,606 & 20 & 23,187 & 0.5 \\
\hline & 中 小 塊 & 464 & 3 & 2,891 & 0.1 \\
\hline & 粉 & 642 & 4 & 3,531 & 0.1 \\
\hline & 計 & 40,215 & 220 & 246,887 & 5.5 \\
\hline & $2,3,4$ 號洗滌炭 & 21,036 & 115 & 89,484 & 2.0 \\
\hline & 切达洗炭 & 454 & 2 & 2,747 & 0.1 \\
\hline & 1 號コ一ク & 4,947 & 27 & 31,364 & 0.7 \\
\hline & 合 & 66,727 & 364 & 370,482 & \\
\hline
\end{tabular}

賣却眝藏合計 - - 397,122 8.9

所内 消 費 $541,423 \quad 2,959 \quad 4,084,391 \quad 91.1$ $\begin{array}{lllll}\text { 總 計 } 731,770 & 3,999 & 4,481,513 & 100\end{array}$ 
$93 \%$ ，重油が 2\%．貯藏から拂出した石炭及コークス のそれが $5 \%$ ，結局 $4,482 \times 10^{9} \mathrm{kcal}$ の熱量か入つ ている。其の中賣却された熱量は $1 \%$ ，來期の䝪藏に 迴つた固體燃料が $8 \%$ で，残りの $91 \%$ は所內で使用 された計算となる。その熱量は $4,084 \times 10^{9} \mathrm{kcal}$ で, 1 日 $22,320 \times 10^{6} \mathrm{kcal}, 1$ 時間 $951 \times 10^{6} \mathrm{kcal}$ の割合 で消費されている。

\section{（A）洗炭工場}

第 11 表で分る如く、 コークス用原料とし, 强战結 炭を $36 \%$, 弱粘結炭を $56 \%$ ，アメリカ上りの輸入炭 を $3 \%$ 洗炭し，粗惡炭堂洗炭したのか５％て，合新 $2,545 \times 10^{9} \mathrm{kcal}$ の熱量を處理している。その内コー

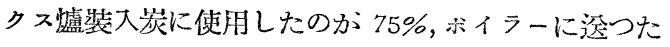
のが 5\%洗炭漳(洗沙炭)が 20\% になる。洗炭.上場に 於て倃用した電力は $2,101 \times 10^{3} \mathrm{KWH}$, 蒸気は 6,020 t 水は $574 \times 10^{3} \mathrm{t}$ てある。

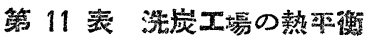

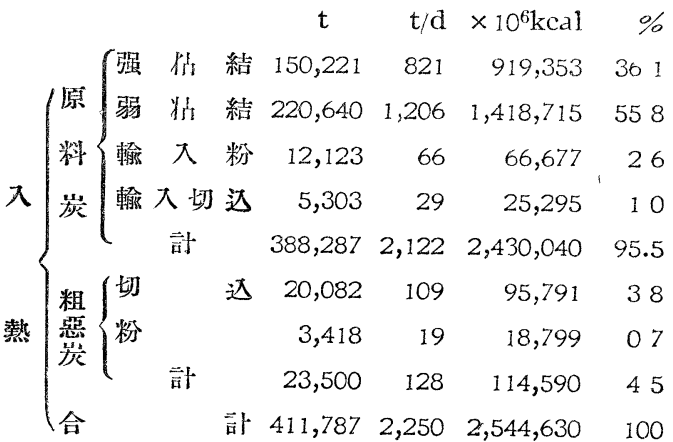

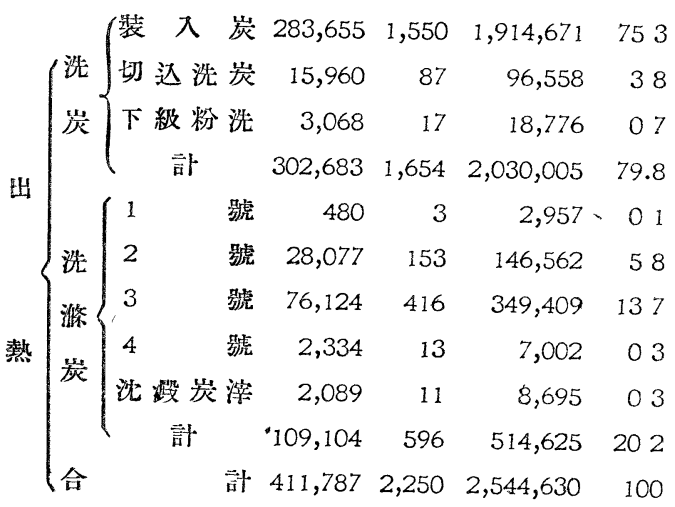
(B) コークス爐

コークス爐は東田及び洞岡の各 1 團か操業されてい るが，その作業狀況は第 12 表の如くて，裝入炭 $\mathrm{t}$ 當 り燃料使用量は $750 \times 10^{3} \mathrm{kcal}$ 程度である。

コークス爐に入る熱量は，1號コークス用装入炭と

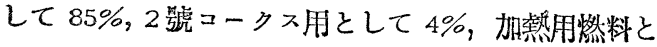
して $11 \%$ て，合計 $2,193 \times 10^{9} \mathrm{kcal}$ でる。情熱で

は製品コークスとして 61\%，ガスとして 20\%，ター 几及輕油として $7 \%$ が持ち出され，殘りの $12 \%$ はコ 一クス爐にて消費された事となる。從つて自己消費は $261 \times 10^{9} \mathrm{kcal}$ である。電力は $2,652 \times 10^{3} \mathrm{KWH}$, 蒸汽

\section{第 12 表 コークス爐作叢}

装入炭 弱粘結 配合割合 强、粘 結

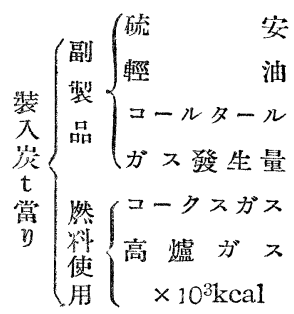

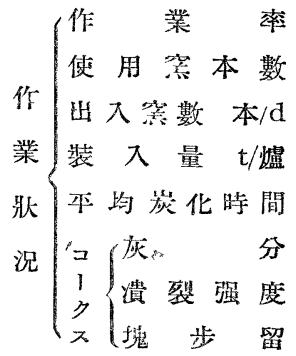

\section{管 13 表}

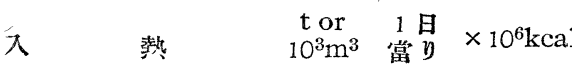

装 $\begin{array}{lllll}1 & \text { 號 装入炭 } 274,920 & 1,502 & 1,855,710 & 84.6\end{array}$

入 2 裝 $\begin{array}{llllllll}1 & \text { 入 } & \text { 炭 } & 8,735 & 48 & 58,961 & 27\end{array}$

物 $\left\{\begin{array}{lllll}\text { 號 ( } 2 \text { 號洗滌峟 } & 7,685 & 42 & 40,116 & 1.8\end{array}\right.$ 计 $291,340 \quad 1,592 \quad 1,954,787 \quad 89.1$

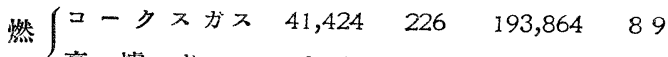
料 $\left\{\begin{array}{lllllll}\text { 高 爐 } & \text { カ } & \pi & 43,960 & 241 & 44,553 & 2.0\end{array}\right.$ $\begin{array}{llll}85,384 & 467 & 238,417 & 10.9\end{array}$ 敦 $\quad-\quad-2,193,204 \quad 100$

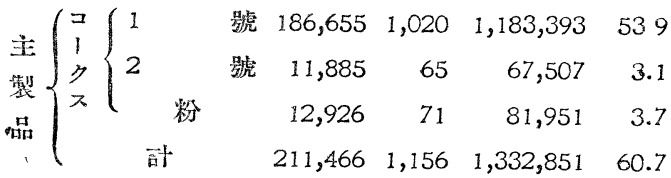

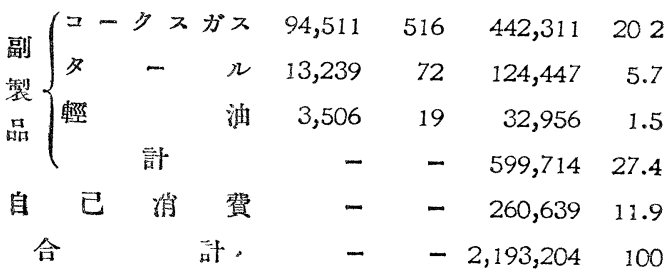


は $6,276 \mathrm{t}$ ，水は $4,730 \times 10^{3} \mathrm{t}$ 使用されている。

(C) 高 爐

東田の No. 3 及び No. 4 (各 $400 \mathrm{t} / \mathrm{d}$ 能力), 润岡 の No. 2(700 t/d) 高爐を操業して 137,000 t の出銑 を行つている。作業狀況及び鉄鐵 $\mathrm{t}$ 當りの装入量や發 生量は第 14 表に示した。

\section{第 14 表高爐作呈}

東田洞阙本均

$\begin{array}{llllrrr} & \text { 鈚 } & \text { 量 } & \mathrm{t} & 72,401 & \text { ・64,897 } & 137,298 \\ \text { 作 業 } & \text { 率 } & \% & 94.5 & 946 & 945\end{array}$

C $\begin{array}{lllll}\mathrm{C} & \% & 341 & 356 & 349\end{array}$

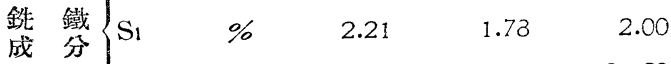

$\begin{array}{lll}0.135 & 0.104 & 0.20\end{array}$

癸 本均量 $\mathrm{m}^{3} / \mathrm{mm} \quad 503 \quad 1,271 \quad 887$

風厚力 $\mathrm{gr} / \mathrm{cm}^{2} \quad 529 \quad 777 \quad 6: 1$

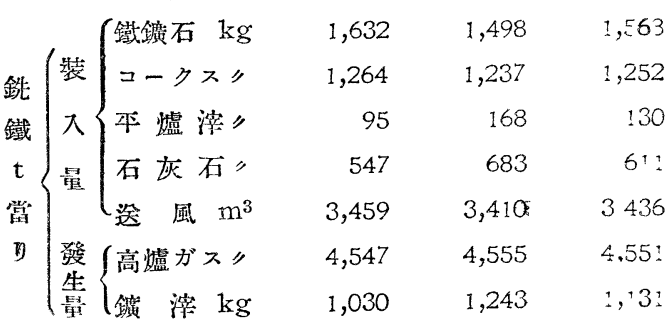

\section{第 16 表 製}

設借 基數

整锏法

良塊生量 $\mathrm{t}$

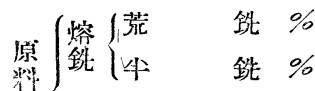

猞 \%

害

鐵 \%

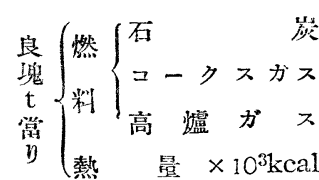

嵌重油 174

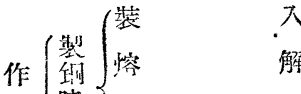

業 卦

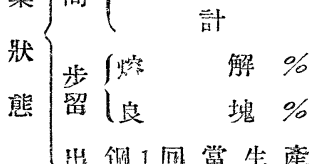

大熱は第 15 表に示す如く，コークスが $82 \%$ ，熱质 㠠用のガスが 17\%，其の他 1\% であり，出熱として は銑鐵の顯㷫が 3\%，鑛涬のそれが $5 \%$ ，高爐がスの 潜熱は放散量る含めて $46 \%$ で, 殘りの $46 \%$ が自己 消費となる。其の他電力は $18,005 \times 10^{3} \mathrm{KWH}$, 蒸汽は

\section{第 15 表高爈の熱平衡}

\begin{tabular}{|c|c|c|c|c|c|c|c|}
\hline & & 針 & & $\begin{array}{c}\text { eor } \\
10^{3} \mathrm{~m}^{3}\end{array}$ & 當 & $\times 10^{6} \mathrm{kc}$ & \\
\hline & 1 呫 & 党 $=-ク$ & z & 171,875 & 939 & $1,089,688$ & 82 \\
\hline & 高 & 爐 カ & z & 236,510 & 1,292 & 227,050 & 17. \\
\hline & & 訫 & & - & - & $1,316,738$ & 995 \\
\hline & 粉 & $=-y$ & z & 544 & 3 & 3,449 & \\
\hline & 2號 & 及3號沉淮 & 焚 & 366 & 2 & 1,765 & \\
\hline & & 込 & & 130 & 1 & 620 & \\
\hline & & 計 & & 1,040 & 6 & 5,834 & 0. \\
\hline 合 & & 市 & & - & - & 1,322 & 10 \\
\hline & & 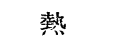 & & & & & \\
\hline & 铑 & & 鐵 & 137,298 & 750 & - 41,189 & 3 \\
\hline & 镜 & & 滓 & 155,247 & 848 & 63,651 & 4 \\
\hline & 高 & 嘘 ガ & z & 629,830 & 3,442 & 604,637 & 45.7 \\
\hline & & 計 & & - & - & 709,477 & \\
\hline & & 消 & & 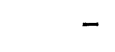 & - & 613,095 & \\
\hline & & & & - & - & $1,222,572$ & \\
\hline
\end{tabular}

\section{鐥作業}

1 製除

$-$

$\therefore$

2 製 细

$60 t \times 10^{200 t \times 2} 300 t \times 1$ (A.M)

普 通 普 通 合 的

41,728

61,627

353

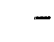

11.9

52.8

543

60

200

1,903

$4^{\circ} 46^{\prime}$

$3^{\circ} 48^{\prime}$

$2^{\mathrm{C}} \mathrm{C}^{\prime}$

$.00^{\circ}+0^{\prime}$

97.1

91.2

$6:$
2,938

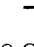

175

343

893

50

301

3,168

$5^{\circ} 24^{\prime}$

$4^{\circ} 17^{\prime}$

$2^{\circ} 09^{\prime}$,

$11^{\circ} 50^{\prime}$

957

889
58
.3 製銅

$60 \mathrm{t} \times 7$

普 通

52,816

38.3

8.9

52.8

545

559

60

205

1,960

$4^{\circ} 48^{\prime}$

$3^{\circ} 49^{\prime}$

$2^{\circ} 06^{\prime}$

$10^{\circ} 43^{\prime}$

971

911

61

1,935

$4^{\circ} 14^{\prime}$

$3^{\circ} 25^{\prime}$

$2^{\circ} \mathrm{O}^{\prime}$

$9^{\circ} 46^{\prime}$

94.6

$\checkmark 963$

63
霄氣蠦

$1 \mathrm{t} \times 23 t \times 1$

$6 \times 3 \quad 10 t \times 2$

孤光式

7,464

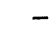

04

996

電力 824
2 8 
$109,897 \mathrm{t}$ ，水は $28,714 \times 10^{3} \mathrm{t}$ 消費されている。

(P) 平爐

第一製鋼工場には $100 \mathrm{t}$ 平爐か 4 基あるか，本均稼 動數は 117 基て，重油專燒でる。第二製鋼工場る $60 \mathrm{t}$ 平爐を 10 基持つているか，平均稼動數は 317 基で，燃料發生爐カスと少量の混和ガスてある。第 三製鋼工場は $60 \mathrm{t}$ 平爐 7 基の中稼動數は 245 基て， 發生爐ガス專燒てある。3者の製銀㭙間は $15 ； 11 ， 10$ 時檪:て，良塊 $\mathrm{t}$ 當り使用熱量は 199，196，194 萬 Kcal て步る。(第 16 表)

第 17 表に示す如く，石炭としての入熱か: $77 \%$, 重

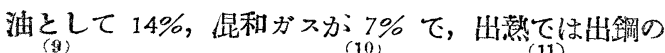

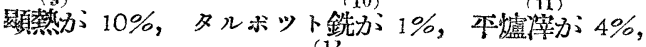
登熱汽篧て回收される蒸汽が $3 \%$ となり，殘りの 82 \%が自己消費となる。電力は $3,002 \times 10^{3} \mathrm{KWH}$, 蒸汽 は 95,235t, 水は 9,805 × $10^{3} \mathrm{t}$ か使用されている。

(E) 鋼材加蓺爐

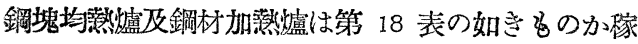
動して扣り，作業時間よりみて，最る順調に動いたの か，3４，5 分塊の 80 1\%，最低は第 1 厚板の $49 \%$ てある。材料 $\mathrm{t}$ 當りの使用熱量は, 最子少いの第 2 山形の $493 \times 10^{3} \mathrm{kcal}$ ，最大か门日畑製鐳の $2,315 \times 10^{3}$ kcal てむる。

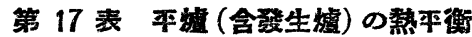

\begin{tabular}{|c|c|c|c|c|}
\hline 熱 & $\begin{array}{l}t \text { or } \\
10^{3} \mathrm{~m}^{3}\end{array}$ & $\begin{array}{l}\text { 1日 } \\
\text { 當 }\end{array}$ & $\times 10^{6} \mathrm{kcal}$ & $\%$ \\
\hline (中 小塊 啖 & 74,737 & 408 & 465,612 & 77.1 \\
\hline 重 & 7,365 & 40 & 73,650 & 12.1 \\
\hline クレオッート油 & 1,009 & 6 & 9,485 & 16 \\
\hline 高爐分 & 15,556 & 85 & 14,934 & 25 \\
\hline コークスガス & 5,260 & 29 & 24,617 & 41 \\
\hline 計 & - & - & 588,298 & 974 \\
\hline $\begin{array}{l}\text { 高爐及コーークス } \\
\text { 方及 }\end{array}$ & 2,935 & 16 & 13,594 & 22 \\
\hline 粉, 切达, 洗策炭 & 299 & 1 & 1,449 & 02 \\
\hline 粉, 2 號コークス & 163 & 1 & 926 & 0.2 \\
\hline 計 & - & - & 15,969 & 26 \\
\hline 計 & - & - & 604,267 & 100 \\
\hline
\end{tabular}

出 蓺

\begin{tabular}{|c|c|c|c|c|c|c|}
\hline ; & 出 & 㼬 & 170,017 & 929 & 57,806 & \\
\hline & タルホッ & 卜钲 & 19,861 & 109 & 5,660 & \\
\hline & 計 & & 189,878 & 1,038 & 63,466 & \\
\hline & 爐 & 漼 & 44,700 & 244 & 22,127 & \\
\hline & 熱 蒸 & 氣 & 32,386 & 177 & 21,310 & \\
\hline & 訊 & & - & - & 43,437 & \\
\hline & 己 & 費 & - & - & 497,364 & \\
\hline & & tit & - & 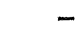 & 604,267 & \\
\hline
\end{tabular}

\section{第 18 表 加熱嘘及均熱嘘作菜}

\begin{tabular}{|c|c|c|c|c|c|c|c|c|c|c|c|}
\hline & & & 作業 & 侍間割合 & & & 本 & 䊀 & 當 & 燃 & \\
\hline & & & 加 埶 & 保 埶 & 休 止 & 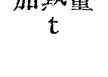 & 获 & 重 & $\begin{array}{l}コ ー ク \\
\text { スガス }\end{array}$ & $\begin{array}{cc}\text { 高 } & \text { 盢 } \\
\text { ガ } & \text { ス }\end{array}$ & $\begin{array}{l}\times 10^{3} \\
\text { kcal }\end{array}$ \\
\hline 3 & 4,5 分 & 瑰 & 801 & 31 & 168 & 57,450 & 150 & - & 24 & 60 & 745 \\
\hline 6 & 分 & 塊 & 391 & 31 & 57.8 & 47,434 & - & - & 38 & 507 & 729 \\
\hline 7 & 分 & 塊 & 22.9 & 287 & 484 & 39,442 & - & - & 141 & 155 & 740 \\
\hline 2 & 犬 & 形 & 451 & 115 & 434 & 19,632 & - & 7 & 65 & 314 & 641 \\
\hline 2 & 中 & 形 & 122 & 88 & 790 & 10,645 & - & 5 & 65 & 180 & 493 \\
\hline 1 & 小 & 形 & 55 & 36 & 90.9 & 1,123 & - & 9 & 124 & 330 & 889 \\
\hline 3 & 小 & 形 & 197 & 154 & 649 & 8,124 & - & 10 & 99 & 187 & 614 \\
\hline 線 & & 材 & 152 & 155 & 693 & 12,552 & - & - & 168 & 222 & 992 \\
\hline 鍜 & & 珮 & 326 & 61 & 613 & 862 & 52 & 201 & - & - & 2,315 \\
\hline 外 & & 輸 & 227 & 460 & 313 & 4,129 & 177 & 79 & - & - & 1,824 \\
\hline 1 & 厚 & 板 & 49 & 65 & 886 & 1,979 & - & - & 104 & 1,100 & 1,482 \\
\hline 2 & 中 & 板 & 237 & 281 & 482 & 6,878 & - & 0.2 & 105 & 382 & 806 \\
\hline 珪 & 素 鈉 & 板 & 355 & 38 & 60.7 & 25,844 & - & - & 147 & 587 & 1,175 \\
\hline$\pi$ & トリッ & $7^{\circ}$ & 56 & 152 & 792 & 14,898 & - & 50 & 121 & - & 978 \\
\hline
\end{tabular}

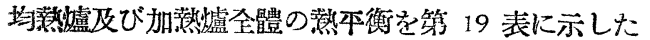
石炭か 25\%，重油が 6\%，ガスが 68\%の割合で入熟 となり，加熱鋼塊の持出す熱量は $22 \%$ ，茂りの 78
\%は自己の消費そなる。電力は $24,530 \times 10^{3} \mathrm{kcal}$, 蒸 汽は $33,995 \mathrm{t}$, 水は $6,875 \times 10^{3} \mathrm{t}$ 嘴費されてい る。 


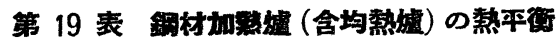

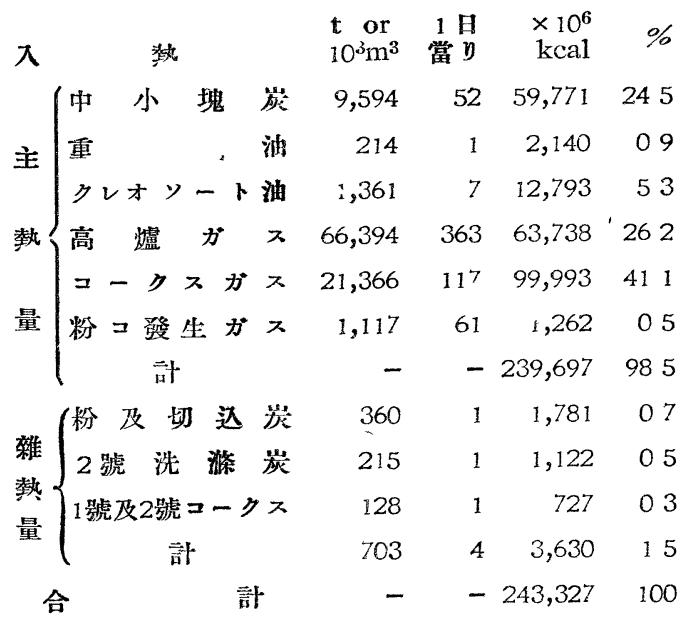

出㙓

銅 材 加 熱 量 $250,992 \quad 1,372 \quad 52,708 \quad 217$

自己 消 費 - $-190,619783$ 合 - - 評 $\quad-243,327 \quad 100$

(F) 鿑 解

主要气气蠸場は西西，枝光，南枝光，洞岡等に所在し 使用熱量は粉炭として 29\%，弱糙結炭か２4\%，粗惡

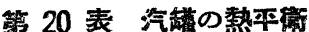

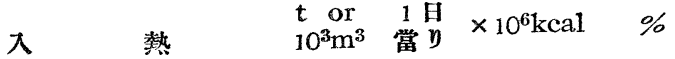

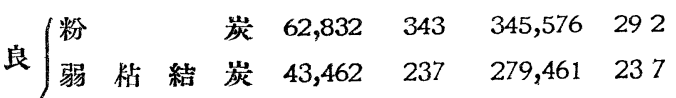

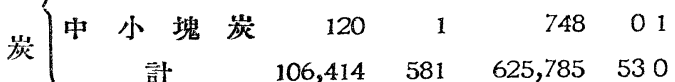

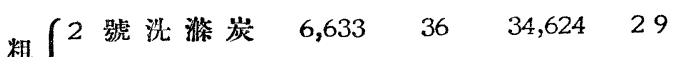

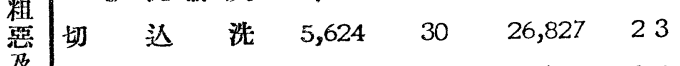

及 $\left\{\begin{array}{lllllll}\text { 下 } & \text { 粐 } & \text { 洗 } & 865 & 5 & 4,758 & 04\end{array}\right.$

$\begin{array}{llllll}\text { 妿混 炭 } & 61,796 & 338 & 343,586 & 292\end{array}$

灰 計 $\quad 74,918 \quad 409 \quad 409,795 \quad 348$

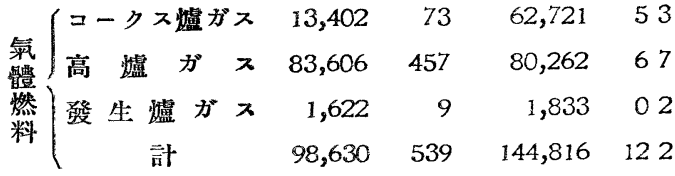

合 評 - $\quad-1,180,396 \quad 100$

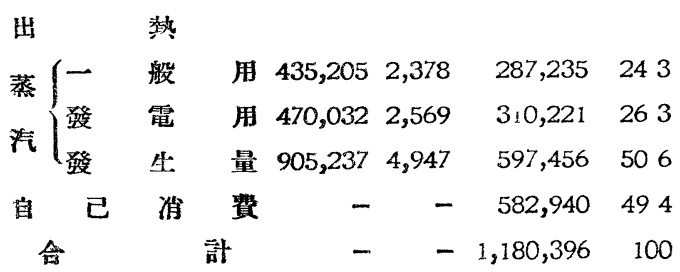

炭及加工炭か 6\%，混炭か 29\%，ガスとして 12\%て ある。發生荥气吸收する熱量が $51 \%$ で，その牛分 ふ發電用に迴つている。自已消費が $49 \%$ て，若干高 い憾がる。

鿑罐場て主に使用する倱炭の配合割合は第 21 表の

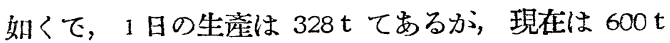
索に越している。

气罐場伐用電力は $40,088 \times 10^{3} \mathrm{KWH}$, 蒸气は40,441 t 水は $10,649 \times 10^{3} \mathrm{t}$ てある。

\section{第 21 表 混炭場の熱平衡}

\begin{tabular}{|c|c|c|c|c|c|}
\hline 入 埶 & 勃 & $\mathrm{t}$ & $\begin{array}{l}1 \text { 日 } \\
\text { 富 }\end{array}$ & $\begin{array}{l}\times 10^{6} \\
\text { kcal }\end{array}$ & \\
\hline 上 級 & 弱佔結炭 & 21,080 & 115 & 13,554 & 385 \\
\hline 級 & 粉 & 19,232 & 105 & 10,578 & 0 \\
\hline 級 & 塊及切込崖 & 780 & 4 & 372 & 1 \\
\hline \multirow{2}{*}{ 先涤琵 } & $\left\{\begin{array}{l}1 \\
1\end{array}\right.$ & 480 & 3 & 296 & 8 \\
\hline & 12 & 9,321 & 51 & 4,866 & \\
\hline \multirow{2}{*}{ 加工岸 } & 凶洗 & 6,613 & 36 & 4,001 & \\
\hline & |下級粉洗 & 2,566 & 14 & 1,570 & \\
\hline 合 & 計 & 60,072 & 328 & 35,237 & \\
\hline & 彭 & & & & \\
\hline & 炭 & 60,072 & 328 & 35,237 & \\
\hline 合 & 計 & 60,072 & 328 & 35,237 & \\
\hline
\end{tabular}

\section{茅 22 表 八幡戥鐵所熱量使用狀況}

\begin{tabular}{|c|c|c|c|c|c|}
\hline \multicolumn{2}{|c|}{ 主 作 } & \multicolumn{2}{|c|}{ 業 } & \multirow{2}{*}{$\begin{array}{c}\times 10^{6} \mathrm{kcal} \\
418,042\end{array}$} & \multirow{2}{*}{$\begin{array}{r}\% \\
102\end{array}$} \\
\hline$=-$ & r & ス & 爐 & & \\
\hline 高 & & & 爐 & $1,121,509$ & 275 \\
\hline 燒 & & & 結 & 53,794 & 13 \\
\hline 本 & & & 爐 & 604,267 & 148 \\
\hline 銅 材 & 加 & 埶 & 堵 & 243,327 & 60 \\
\hline & के & & & $2,440,939$ & 59.8 \\
\hline 副 & 价 & & 業 & & \\
\hline 汽 & & & 篗 & $1,180,396$ & 288 \\
\hline 化 & & & 成 & 20,783 & 05 \\
\hline 爐 & & & 材 & 31,640 & C 8 \\
\hline 粉コ一 & -クス & 發唀生 & 生 盧 & 11,275 & 03 \\
\hline$I$ & & & 作 & 69,063 & 17 \\
\hline 運 & & & 輸 & 118,521 & 29 \\
\hline セ & $x$ & ン & ト & 12,638 & 03 \\
\hline 石灰 & Fロ & $\nabla$ & $1 卜$ & 64,570 & 16 \\
\hline 電 & & & 爐 & 724 & - \\
\hline 其 & & & 他 & 133,842 & 33 \\
\hline & 言 & & & $1,643,452$ & 402 \\
\hline 所 & 丙 & 俏 & 費 & $4,084,391$ & 100 \\
\hline
\end{tabular}




\section{[V]八幡製鐵熱量使用狀况}

第 4 章にて說明したような熱本衡を，以上の外に烓 結, 化成, 爐材, 粉コーク又發生㠠, 工作, 運輸, 七 メント，石灰ドロマイト，電爐工場に就いても行つた が，紙面の割合て割愛し，その結果から八幡製鐵所熱 量使用狀況を調查飞たのが第 22 表である。全熱量の 60\%が主作業に 40\% が副作業に使用されている。然 乙副作業と言つても，之と切離しては主作業も成り立 たない。

\section{[VI] 熱 流れ 圖}

以上の說明により然料を主とした熟流れ圖を作成す れば第 1 圖の如くなる。その說明は第 5 章と同栐であ る。電力, 蒸汽をる加之全熱量の平衡圖は第 2 圖の通 りで, 燒結，七メント等消費工場の゙热量使用割合が左 邊のブロック內に示されている。

\section{[VII] 總䄽}

昭和 22 年下期に於ける實績をるとにして, 然料(石 炭, コークス, 加工炭, 洗源炭, 液體燃料, 高盧がス, コークス㠠がス等) 及び補助熱量 (電力, 蒸汽，水) の需給狀況を萒明し，それを基凖として熱計算を行い 八幡製鐵所全體の熱斥衡を示して後, 洗炭工場, コー クス爐，高爐，平㠠，鋼仏加熱盧，汽罐等各個につい ての熱龶衝結果を示した。
以上を總括して八幡製鐵所の熱量使用狀況を表示し 最後に燃料のみの熱流れ圖と, 電力, 蒸汽を加之た棕 合㷫流れ圖を作成した。

（附記）本報告の作成に當つては監理部長牛尾糜㸔

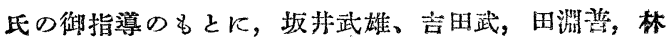
勝藏の諸氏の協力を得た。謹んで謝意を表する。

（1）燃料の總發熱量 (Hokcal $/ \mathrm{kg})$ 㫐發熱量 (Hu $\mathrm{kcal} / \mathrm{kg}$ ) 凡換算するに核（設樂正雄「汽罐士」昭和 21 年 9 月 p. 30)

$$
\mathrm{Hu}=\mathrm{Ho}-600\left\{9\left(\mathrm{H}-\frac{\mathrm{O}}{8}\right)+\mathrm{W}\right\}
$$

を使用す水ばよい。然し燃料中の水素 $(\mathrm{H})$ 及び酸 素 (O) К就ては一々測定认行っていせいので，熼 際問題としては困難なので省略した。

（2） 2 號コークスは1號コークスの代用品てあるか ら，庅分は $21.41 \%$ 儿對して $29.84 \%$ ，潰裂强度（ $\boldsymbol{F}$ ラムテスト) は 90.02 K對して 7630 と品質は劣化 している。

（3）(設樂正雄「技術々経營」昭 22 年 10 月 p.27) に「炭質低下と製鐵作業」なる題のもとと詳細に境 明している。

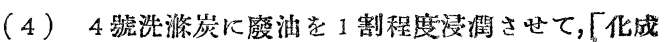
炭」として機關車その他に傸用する。洋細々「燃料

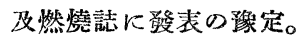

\section{第 1 図}

八幡製鐵所热流圆

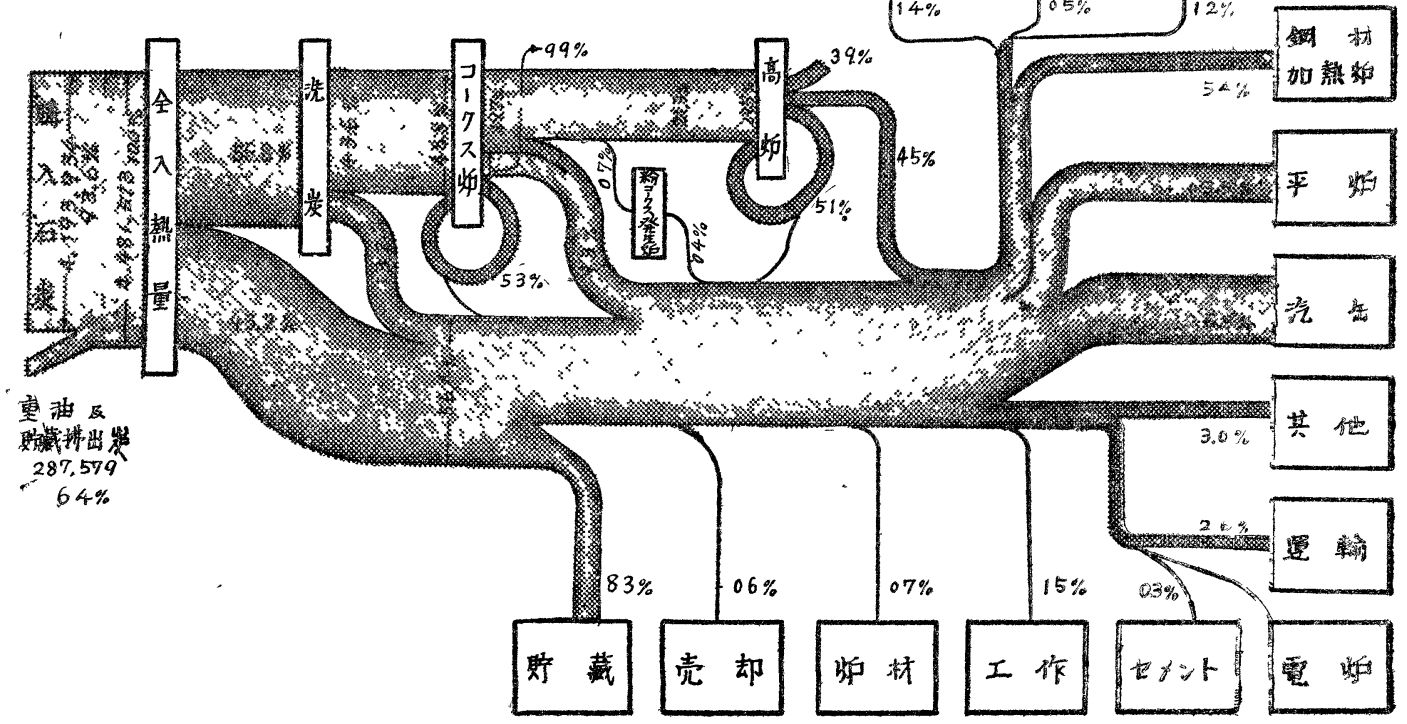




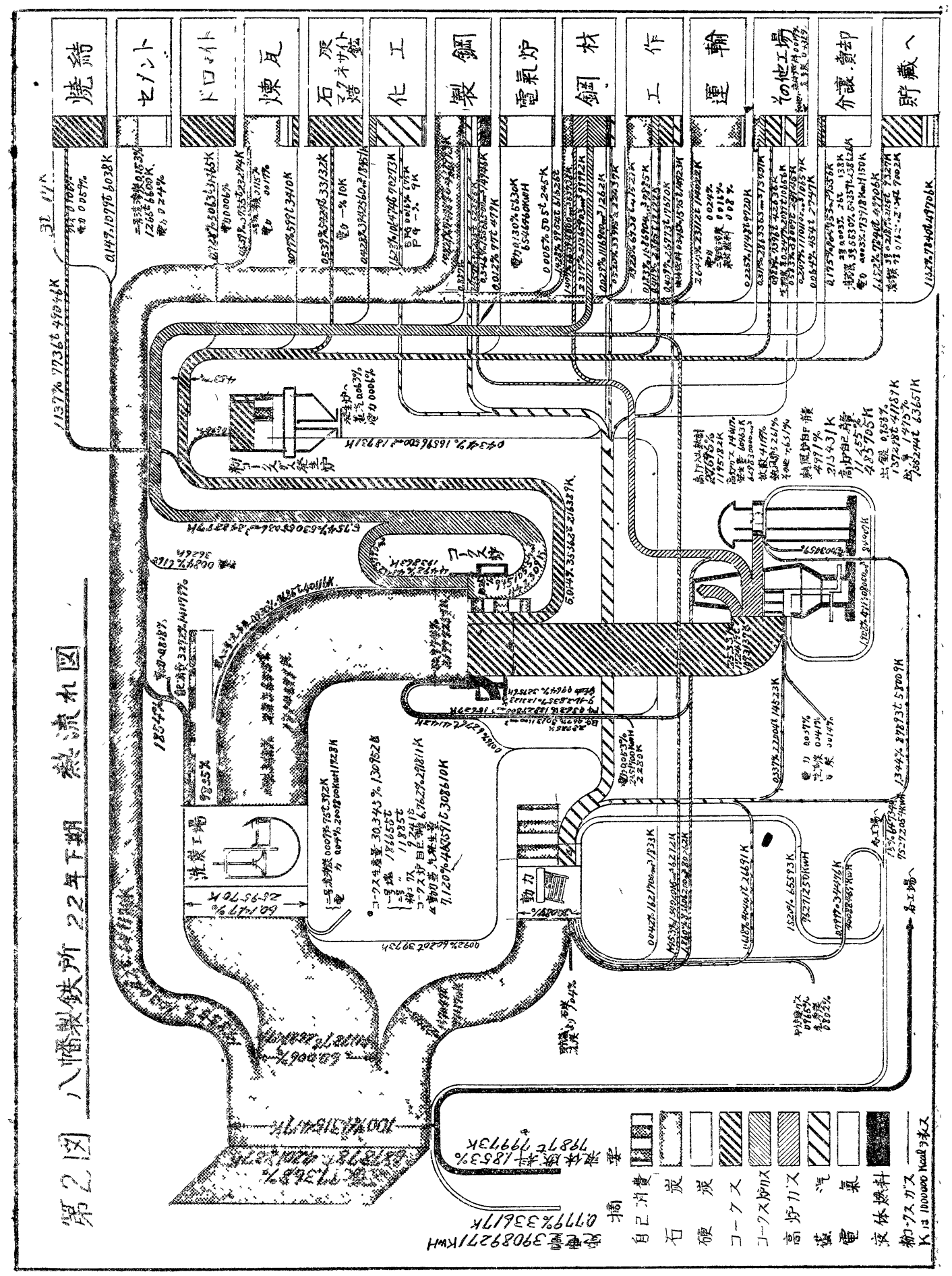


（5）コークス爐のの燃料には貧ガスを使用し發生し

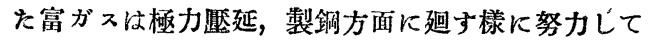
いるそのために高爐がスを同岡の復式コークス爐 に使用している。

（6）粉コークス處理の目的て建吺したコッパース式 發生爐て 9 基ある。

（７）設樂正雄「工業攽爐」昭 23 年 2 月 p 7 Kよ 熔鉄の溫度 $1,420^{\circ} \mathrm{C}$, 平均比熱 $0210 \mathrm{kcal} / \mathrm{kg}$ てあ るから，その熱含量な $300 \mathrm{kcal} / \mathrm{kg}$ となる。

（8）熔㵏の温度 $1,450^{\circ} \mathrm{C}$ てその比熱が $0.287 \mathrm{kcal} /$ $\mathrm{kg}$ てあるから, 热含量は $410 \mathrm{kcal} / \mathrm{kg}$ となる。(設 樂正雄, 同誌 $\mathrm{p} 8$ )

（9）摈崄泪度 $1,620^{\circ} \mathrm{C}$ でその比熱が $0.209 \mathrm{kcal} / \mathrm{kg}$
てあるから，熱含量は $340 \mathrm{kcal} / \mathrm{kg}$ となる。

（10）タ光ホット銚は $1,350^{\circ} \mathrm{C}$ て比熱は $0212 \mathrm{kcal}$

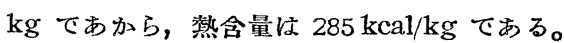

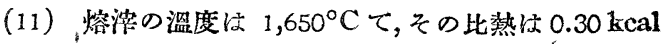
$/ \mathrm{kg}$ であから，熱含量は $495 \mathrm{kcal} / \mathrm{kg}$ となる。

（12）蒸汽溫度は $150^{\circ} \mathrm{C}$ で厴力は $4 \mathrm{~kg} / \mathrm{cm}^{2}$ であるら

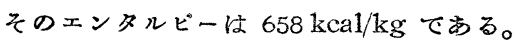

（13）分塊 $144,326 \mathrm{t}$ ， 噼延 106,666t で合計が 250,992t

（14）銅材の加熱溫度 $1,250^{\circ} \mathrm{C}$ 比熱を $0.165 \mathrm{kcal} / \mathrm{kg}$ とすれば，熱含量は $210 \mathrm{kcal} / \mathrm{kg}$ である。

（15）電力の理論熱量は $860 \mathrm{kcal} / \mathrm{KWH}$ であるが, 火力發電による䝷際の所要熱量注はるかに高いるの となる。

\section{休止コークス爐の高爐ガス燃燒による完全操業に至る迄}

一昭和 24 年 7 月 11 日第 244 回例會諽演——

釜石製鐵所西尾醇

[I] 緒

コークス爐は一旦完全に冷却休止した時は再閉には 爐體に相當な手入れを要し，省之ががス加熱には操業 後る常に手入をせねはならないのか潽通てある。

又一方高爐がス加熱を探用する休止大型コ一クス爐 の完全操業は我國に於ては最初の試みであつた，或は 世界で它例かなかつたか子知れない。之によりコーク 又爐の加熱については常時手入を行わすして樂な作業 か出來且燃燒室も高溫となり，公出本數る啫加出來て 現在順調に操栄している。

休止コークス爐の再閉は米國モルガンタウン兵器工 場のコークス爐（ウイルプソトアンダーチュツト式） 齐 37 基 2 團かあるが (Morgan town operation. Blast furnace \& Steel plant Vol 34, No. 11, Nov 1946), 之はコークス爐カス加熟であり且操業開 始より休止迄の期間がモルガンタウンのA爐 3 年 4 ケ
月, B㠠 3 年9ケ月に比し釜石コークス爐（日絟式復 式）ては第五爐，5年牛，第六爐，6年餘主經過して 老令に澾しており, 且モルカ゚ンタウン工場のは經營上 休止する事により充分計畫的休止したのに反し，釜石 コークス爐は戰災を受け機械没備にる多大な被害を受 けて突然の休止てあつて充分な準備力出來なかつた感 雨水が相當侵入して劣且東北の塞冷地にある黨凍結す るので之には冬期保溫法を行つた（コークス㠠冬期保 溫「鐵と罁」34年, 7 號, 昭和 23 年 7 月 5 〜 頁)。 之は簡單にして經費の少ない特別新構想により熱風を ガスダクトより吹込夕爐全體を $10^{\circ} \mathrm{C}$ 程度に保ち, 昭 和 20 年より 23 年过冬期間之を絽返して盢體內の膨大 な结石煉瓦を保護した。

\section{[II]遥石コークス嘘の綎歷}

金石コータス爐の經歴は次表の如くでる。

\section{第 1 表}

\begin{tabular}{|c|c|c|c|c|c|c|c|c|}
\hline 名 & 型 & 爐長 $\times$ 巾 $\times$ & 筧數 & 裝大量 & 操業開始 & 休 & 止 & 再。 \\
\hline 二ニークス㭗 & 日驖複式 & $12,000 \times 400 \times 4,000 \mathrm{~mm}$ & 45 & 12.01 & 昭18.1220 & 昭20 & 12.22 & 入 \\
\hline 三コークス爐 & 釜石複式 & $12,000 \times 330 \times 4,000$ & 30 & 10.0 & 昭 $8 \quad 524$ & 昭18. & 10.17 & 日踛式 \\
\hline コークス爐 & 黑田複式 & $12,000 \times 4 \mathrm{CO} \times 4,000$ & 35 & 120 & 昭11. 7. 4 & 昭20. & 614 & 計 \\
\hline 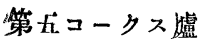 & 日舅複式 & $13,200 \times 400 \times$ & 32 & 13.0 & 昭13.12.31 & 昭20 & 7. 14 & 5. 4 \\
\hline - & 日鐵 & $13,200 \times 400 \times 4,000$ & & 130 & 昭14 & 昭 20 & 7.14 & 昭 23.5 .28 \\
\hline
\end{tabular}

